\title{
EXAMINATION OF THE NOTES TO THE FINANCIAL STATEMENT THROUGH THE EXAMPLE OF ENTERPRISES ENGAGED IN SPORTS ACTIVITIES
}

\section{SZÁMVITELI BESZÁMOLÓK KIEGÉSZÍTó MELLÉKLETEINEK VIZSGÁLATA A SPORTTEVÉKENYSÉGGEL FOGLALKOZÓ VÁLLALATOK PÉLDÁJÁN}

\author{
Veronika Fenyves ${ }^{1}$, Dóra Kerezsi ${ }^{1}$, Éva Bácsné Bába ${ }^{2}$, Krisztina Dajnoki 3, Zoltán Bács ${ }^{1}$, \\ Tibor Tarnóczi ${ }^{1}$ \\ ${ }^{1}$ Institute of Accounting and Finance, Faculty of Economics and Business, University of Debrecen, \\ Hungary \\ ${ }^{2}$ Institute of Rural Development, Tourism and Sports Management, Faculty of Economics and \\ Business, University of Debrecen, Hungary \\ 3 Institute of Management and Organisation Sciences, Faculty of Economics and Business, University \\ of Debrecen, Hungary
}

\author{
Keywords: \\ Financial statement, \\ Text mining, \\ Information, \\ Sports activity \\ Kulcsszavak: \\ Számviteli beszámoló, \\ Szövegbányászat, \\ Információ, \\ Sporttevékenység
}

\begin{abstract}
In the globalized and accelerated world of our time, it is essential that enterprises have upto-date information. Only a company that is in possession of the necessary information is able to meet the challenges of business life. One source of public information might be the annual statement prepared and published in accordance with the stipulations of Act $C$ of 20oo. The annual statement consists of three parts: the balance sheet, the profit and loss account and the notes to the financial statement. The text-based information of the notes to the financial statement are for the more accurate interpretation of numerical data. The notes to the financial statement of certain market participants (consumers, suppliers, competitors, etc.) might support efficient operation of companies, their proper decision-making and risk assessment. In present study, the notes to the financial statement of companies identifying sports activities (Hungarian NACE 931) as their primary activity were utilized. By means of text mining, it was examined what information these notes to the financial statement include from amongst the mandatory information required by the Accounting Act.
\end{abstract}

\section{Összefoglalás}

\footnotetext{
1 Fenyves Veronika. Tel.: +36 52521 900; fax: +36 52526941

E-mail cím: fenyves.veronika@econ.unideb.hu
} 
A mai globalizált és felgyorsult világban nélkülözhetetlen, hogy a vállalkozások naprakész információkkal rendelkezzenek. A gazdasági élet kihívásainak az a vállalat tud megfelelni, amely rendelkezik a szükséges információkkal. A nyilvános információk egyik forrása lehet a 20oo. évi C. törvény előirásai alapján elkészített és közzétett számviteli beszámoló. A számviteli beszámoló három részbool áll, a mérlegből, az eredménykimutatásból és a kiegészítő mellékletböl. A kiegészítő melléklet szöveges információi a számszerü adatok pontosabb értelmezéséhez szükségesek. A vállalatok hatékony müködéséhez, a megfelelő döntéshozatalhoz, a kockázatok értékeléséhez nyújthat segítséget egy-egy piaci szereplö (vevők, szállítók, versenytársak stb.) kiegészítő melléklete. Jelen tanulmányban a 931-es TEÁOR számú, fötevékenységként Sporttevékenységet megadó vállalatokat kiegészítő mellékleteit használtuk fel. Szövegbányászat segítségével azt vizsgáljuk, hogy a kiegészítö mellékletek milyen információkat tartalmaznak a számviteli törvény általi elöírt kötelezö információk közül.

\section{Introduction}

In our time, competition amongst enterprises has become much more intense; information, knowledge and promptness are of paramount importance for decision-making. Being well informed is a fundamental requirement for a company to function successfully. Challenges of business life can only be met by companies that possess the necessary information and are able to convert it rapidly into organisational knowledge. In order for companies to be well assessed and evaluated by market participants (consumers, suppliers, financial institutions, competitors, etc.), a reliable and unified information system is required for both the given enterprise and its environment. This requirement has met by the accounting system of companies, which in Hungary is stipulated by the Act $\mathrm{C}$ of 2000 on Accounting. Accounting approached from one side is an internal information system, while observing it from another perspective its main task is to provide information towards the external environment in accordance with the legal requirements [5]. Present study discusses how and to what extent the balance sheet-related specific parts of the notes to the financial statement of companies primarily engaged in sports activities in Hungary provide the information that is indispensable for a proper interpretation of the balance sheet and profit and loss account.

\section{Literature review}

Parts of the financial statement differ depending on the type of the given statement. In addition to the balance sheet and profit and loss account, the notes to the financial statement is also a crucial part of the financial statements in the case of the annual statement, the consolidated annual statement and the simplified annual statement. The Accounting Act specifies the data content of each type of the financial statement in its sections concerning the given statement type, while on the other hand, it provisions the justification of changes and modifications occurred since the last business year and the introduction of their effects in the notes to the financial statement [2]. These data provide market participants with information about the financial situation, assets and liabilities and their changes, financial and profitability situation and plans of the company, providing a reliable and realistic picture [7] [3]. Found that the Accounting Act requires a number of additional information to explain the numerical part of the statement, in line with the principle of clarity and in order to protect the interests of external stakeholders. Without notes on the financial statement, which contains adequate information, effective utilisation of the balance sheet and profit and loss account might be problematic. In his study, Kántor, B. [4] discusses that there are still businesses that introduce certain values of the balance sheet and profit and loss account inadequately (if they do at all), because they are afraid that their competitors might find out certain facts and information about their activity and efforts. However, according to the effective legal provisions, preparation of the notes on the financial statement - aside from certain components - is compulsory, and its content in terms of data and information is regulated. Therefore, sufficient time and energy should be dedicated to its elaboration and the publication of relevant information by both the management and the expert(s) carrying out bookkeeping tasks. 
The Accounting Act specifies all the information that shall be presented in the notes to the financial statement, but it does not classify them. Information concerning the data content of the notes to the financial statement and related to its certain parts are only loosely listed within the Accounting Act. In the case of the annual statement and for the sake of practical utilisation, this information are logical to be classified into three major parts. Therefore, the following parts are distinguished:

- General part, which is mostly intended to serve the better understanding of the data included by the annual statement,

- Informative part, which can be linked to the operation of the enterprise and which supports the better comprehension of the situation of the company,

- Specific part, where the relevant information is linked to the numerical data represented by the balance sheet and profit and loss account and their details and explanations are introduced [2].

In the scope of the specific part of the of the notes to the financial statement such additional information shall be presented in connection with the balance sheet and the profit and loss account that provides easier understanding, comparability and possibility for further analysis [4].

\section{Material and methods}

For the analysis, the notes to the financial statement of companies, which have sports activities (Hungarian NACE No. 931) as their main line of business, were examined. The database included enterprises, which published an annual statement concerning the year of 2017. The survey involved 1747 companies, 1616 of which had notes to the financial statement (the rest of the organizations either did not upload a notes to the financial statement or were obliged to prepare a statement for micro-enterprises, where notes to the financial statement is not a mandatory part). Thus, the survey managed to process the notes to the financial statement of 1616 companies, which is $92.50 \%$ of the total. The analyses were carried out by means of various packages of the $\mathrm{R}$ statistical system. By means of text mining, the study analysed the extent to which the notes to the financial statement provide the necessary information that would be indispensable for the proper interpretation of the balance sheet and the profit and loss account.

Over the past two decades, text mining has gained more and more interest in both academic areas and in business intelligence applications. Text mining means the ability to acquire useful and novel knowledge, which could influence the decision-making of the involved parties through processing large amounts of unstructured text. There is another definition, according to which, text mining is a processing procedure in the course of which a suitable insight into the text can be obtained [6]. More and more text-like databases are created in computer readable formats that require rapid processing. Text mining is an interdisciplinary research field that utilizes various tools of computer science, linguistics and statistics [1].

\section{Results}

Notes to the financial statement of the analysed 1616 enterprises were classified by the applied type of financial statement (Table 1).

Examination of the applied types of financial statements shows that 158 of the involved 1616 enterprises prepare annual statements (9.78\%), while the number of enterprises that apply simplified annual statements is 1333 (82.49\%). Apart from the above, 125 (7.73\%) companies did not specify in their notes to the financial statement the applied type of their financial statement, which is an inadequacy according to the provisions included in the Accounting Act.

Table 1 Classification of the analysed notes to the financial statement by the applied financial statement type (unit of measure: pcs.) 


\begin{tabular}{|l|r|r|}
\hline \multicolumn{1}{|c|}{ Financial statement type } & pcs. & \multicolumn{1}{c|}{$\%$} \\
\hline Not specified & 125 & $7.73 \%$ \\
\hline Simplified annual statement & 1333 & $82.49 \%$ \\
\hline Annual statement & 158 & $9.78 \%$ \\
\hline Total & 1616 & $100.00 \%$ \\
\hline
\end{tabular}

Present study deals with demonstrating the appearance of the information that belongs to the specific part related to the balance sheet within the notes to the financial statement, in the case of companies, which have sports activities as their primary line of business (Tables 23 ) in total and broken down by the type of their financial statement. As mentioned above, the Accounting Act does not compulsorily stipulate for business entities to include a so-called "Specific part belonging to the balance sheet" in their notes to the financial statement, but it does require them to include information, which serve the better understanding of data included by the annual statement. In accordance with legal provisions, this information shall be presented in the same order, as the entries included in the balance sheet and profit and loss account.

Table 2 Appearance of the addition related the asset side of the balance sheet in the notes to the financial statement broken down by the type of financial statements (unit of measure: pcs.)

\begin{tabular}{|c|c|c|c|c|c|c|c|c|}
\hline \multirow{3}{*}{\begin{tabular}{l}
\multicolumn{1}{c}{ Searched term } \\
$\begin{array}{l}\text { Examined } \\
\text { companies }\end{array}$
\end{tabular}} & \multirow{2}{*}{\multicolumn{2}{|c|}{ Total }} & \multicolumn{6}{|c|}{ Type of financial statement } \\
\hline & & & Nots & pecified & \multicolumn{2}{|c|}{ Simplified annual } & \multicolumn{2}{|c|}{ Annual } \\
\hline & 1616 & $100 \%$ & 125 & $100 \%$ & 1333 & $100 \%$ & 158 & $100 \%$ \\
\hline $\begin{array}{l}\text { Addition related to } \\
\text { the balance sheet }\end{array}$ & 798 & $49.38 \%$ & 44 & $35.20 \%$ & 687 & $51.54 \%$ & 67 & $42.41 \%$ \\
\hline Fixed assets & 1174 & $72.65 \%$ & 84 & $67.20 \%$ & 975 & $73.14 \%$ & 115 & $72.78 \%$ \\
\hline Intangible assets & 1079 & $66.77 \%$ & 75 & $60.00 \%$ & 882 & $66.17 \%$ & 122 & $77.22 \%$ \\
\hline Tangible assets & 1419 & $87.81 \%$ & 94 & $\mathrm{o} \%$ & 1176 & $88.22 \%$ & 149 & $94.30 \%$ \\
\hline $\begin{array}{l}\text { Financial } \\
\text { investments }\end{array}$ & 520 & $32.18 \%$ & 29 & $23.20 \%$ & 420 & $31.51 \%$ & 71 & $44.94 \%$ \\
\hline Current assets & 1139 & $70.48 \%$ & 83 & $66.40 \%$ & 938 & $70.37 \%$ & 118 & $74.68 \%$ \\
\hline Inventories & 1204 & $74.50 \%$ & 72 & $57.60 \%$ & 1008 & $75.62 \%$ & 124 & $78.48 \%$ \\
\hline Receivables & 1402 & $86.76 \%$ & 87 & $69.60 \%$ & 1174 & $88.07 \%$ & 141 & $89.24 \%$ \\
\hline Securities & 581 & $35.95 \%$ & 33 & $26.40 \%$ & 477 & $35.78 \%$ & 71 & $44.94 \%$ \\
\hline Liquid assets & 963 & $59.59 \%$ & 56 & $44.80 \%$ & 789 & $59.19 \%$ & 118 & $74.68 \%$ \\
\hline Accruals & 763 & $47.22 \%$ & 36 & $28.80 \%$ & 646 & $48.46 \%$ & 81 & $51.27 \%$ \\
\hline $\begin{array}{l}\text { Opening gross } \\
\text { value }\end{array}$ & 30 & $1.86 \%$ & 1 & $0.80 \%$ & 23 & $1.73 \%$ & 6 & $3.80 \%$ \\
\hline Closing gross value & 21 & $1.30 \%$ & 1 & $0.80 \%$ & 14 & $1.05 \%$ & 6 & $3.80 \%$ \\
\hline $\begin{array}{l}\text { Accumulated } \\
\text { depreciation }\end{array}$ & 154 & $9.53 \%$ & 5 & $4.00 \%$ & 113 & $8.48 \%$ & 36 & $22.78 \%$ \\
\hline Impairment loss & 227 & $14.05 \%$ & 7 & $5.60 \%$ & 168 & $12.60 \%$ & 52 & $32.91 \%$ \\
\hline
\end{tabular}

In the scope of the study, it was examined, how many business entities included the term „related to the balance sheet” in their notes to the financial statement. 51.62\% of the analysed 
sample did not include the searched term, while $49.38 \%$ (798 pcs.) did within the notes to the financial statement. Generally, this is not problematic, since as mentioned above it is not a mandatory element of the notes to the financial statement.

Information related to the asset side of the balance sheet is shown in Table 2. According to the Accounting Act, gross opening value of intangible assets and tangible assets, their increase and decrease, their closing value and reclassifications as well as the opening value, increase, decrease, closing value and reclassifications of accumulated depreciation, total amount of depreciation of the current financial year shall be presented broken down by at least balance sheet entries. Analysis of the data in Table 1 shows that $87.81 \%$ of the enterprises included the term tangible asset in the notes to the financial statement, thus the same enterprises had tangible assets. However, less than 10\% presented the accumulated depreciation and opening and closing gross values, which are considered mandatory information by the Accounting Act. Examining the data in the table, it is clear that the information published by the companies preparing the annual statements is also deficient, but for these companies, ratios are higher than the ratios representing simplified annual statements. Further observations are required to explain why such a large amount of inventory-related information is included in the notes to the financial statement of servicing companies.

Information related to the liabilities side of the balance sheet is detailed in Table 2. As the table shows, only $79.02 \%$ of the companies disclose information related to equity in their notes to the financial statement. After tax profit or loss is mentioned by $18.69 \%$ of the enterprises, which is a very low value. Information related to the distribution of after tax profit or loss should be presented by the companies in any case.

Table 2: Appearance of the addition related the liabilities side of the balance sheet in the notes to the financial statement broken down by the type of financial statements (unit of measure: pcs.)

\begin{tabular}{|c|c|c|c|c|c|c|c|c|}
\hline \multirow{3}{*}{$\begin{array}{l}\text { Searched term } \\
\text { Equity }\end{array}$} & \multirow{2}{*}{\multicolumn{2}{|c|}{ Total }} & \multicolumn{6}{|c|}{ Type of financial statement } \\
\hline & & & \multicolumn{2}{|c|}{ Not specified } & \multicolumn{2}{|c|}{ Simplified annual } & \multicolumn{2}{|c|}{ Annual } \\
\hline & 1277 & $79.02 \%$ & 89 & $71.20 \%$ & 1068 & $80.12 \%$ & 120 & $75 \cdot 95 \%$ \\
\hline Share capital & 996 & $61.63 \%$ & 51 & $40.80 \%$ & 832 & $62.42 \%$ & 113 & $71.52 \%$ \\
\hline Capital reserve & 501 & $31.00 \%$ & 26 & $20.80 \%$ & 413 & $30.98 \%$ & 62 & $39.24 \%$ \\
\hline $\begin{array}{l}\text { Accumulated profit } \\
\text { reserve }\end{array}$ & 822 & $50.87 \%$ & 40 & $32.00 \%$ & 688 & $51.61 \%$ & 94 & $59.49 \%$ \\
\hline $\begin{array}{l}\text { After tax profit or } \\
\text { loss }\end{array}$ & 302 & $18.69 \%$ & 33 & $26.40 \%$ & 231 & $17.33 \%$ & 38 & $24.05 \%$ \\
\hline Liabilities & 1517 & $93.87 \%$ & 109 & $87.20 \%$ & 1259 & $94.45 \%$ & 149 & $94.30 \%$ \\
\hline $\begin{array}{l}\text { Long-term } \\
\text { liabilities }\end{array}$ & 588 & $36.39 \%$ & 40 & $32.00 \%$ & 476 & $35.71 \%$ & 72 & $45.57 \%$ \\
\hline $\begin{array}{l}\text { Short-term } \\
\text { liabilities }\end{array}$ & 894 & $55 \cdot 32 \%$ & 75 & $60.00 \%$ & 724 & $54.31 \%$ & 95 & $60.13 \%$ \\
\hline Provisions & 608 & $37.62 \%$ & 41 & $32.80 \%$ & 498 & $37.36 \%$ & 69 & $43.67 \%$ \\
\hline Deferrals & 746 & $46.16 \%$ & 40 & $32.00 \%$ & 621 & $46.59 \%$ & 85 & $53.80 \%$ \\
\hline
\end{tabular}

Analysis of the notes to the financial statement shows that the majority of the involved companies (90\%) published information about liabilities and short-term liabilities were mentioned by a larger proportion of the companies. Deferrals are detailed by $46.16 \%$ of the companies. 


\section{Conclusions}

Information of the notes to the financial statement would be essential for the complex understanding of the financial statement for different market participants, stakeholders and users. Being adequately informed is an indispensable condition of the successful operation of a business entity. Therefore, information, knowledge and speed are crucial in terms of decision-making. Decision-making based on inadequate knowledge further increases economic risks that are already high. However, financial statements should help reduce the risk through more established decision-making, since notes to the financial statement including proper information would ensure that market participants are properly informed. In the case of the 1616 notes to the financial statement, it can be stated that they showed deficiencies in terms of all legal provisions related to the additional part belonging to the examined balance sheet. Information of the notes to the financial statement of the surveyed business entities are incomplete, they do not comply with the requirements of the Accounting Act, thus obligation for disclosure of market participants on the reliable and realistic picture of their business management is not fulfilled.

\section{Acknowledgements}

The publication is supported by EFOP-3.6.2-16-2017-00003 project. The project was implemented with the support of the European Union, with the co-funding of the European Social Fund.

\section{Bibliographical References}

[1] Feinerer, I. (2008): “An Introduction to Text Mining in R.” In: R News, 8(2) pp. 19-22. https://cran.r-project.org/web/packages/tm/vignettes/tm.pdf [Accessed: 17-May-2018]

[2] Fridrich, P. - Simon, Sz. (2018a): Kiegészítő melléklet I. rész. In: Számviteli tanácsadó, 10 (5) pp. 2-12.

[3] Fridrich, P. - Simon, Sz. (2018b): Kiegészítő melléklet II. rész. In: Számviteli tanácsadó, 10 (7-8) pp. 2-7.

[4] Kántor, B. (2016): A kiegészítő melléklet. In: Számviteli tanácsadó, 8 (3), pp. 2-11.

[5] Kerezsi, D. (2017). A kiegészítő melléklet szerepe a piaci szereplők tájékoztatásában. In: International Journal of Engineering and Management Sciences [Műszaki és Menedzsment Tudományi Közlemények] 2(4) pp. 202-222.

[6] Kwartler, T. (2017): Text Mining in Practice with R. Wiley.

[7] Musinszki, Z. (2016): Pénzügyi mutatókon innen és túl. In: Észak-magyarországi Stratégiai Füzetek, 13 (2) pp. $71-80$. 